\title{
NEW MODELS OF CARE IN IBD IN CHANGING TIMES
}

Dr Peter De Cruz, Head of Inflammatory Bowel Disea se Service Austin Health; Senior Lecturer - Department of Medic ine - The University of Melb oume

\section{ppdecruz@gmail.com}

The goals and expectations of inflammatory bowel disea se (IBD) care have undergone a paradigm shift, which has had a signific ant impact on health care delivery. Recent expert guid elines suggest that clinic al ta rgets such as resolution of abdominal pain, rectal bleeding and nomalization of bowel habit should be corroborated by objective markers including end osc opy or non-inva sive markers such as C-Reactive Protein (CRP) and fecal Calprotectin. Such a "treat-to-ta rget" a pproach is a imed at a chieving muc osal healing but whether such "tight-control" improves outc omes compared to conventional management based on traditional clinical disease indicesalone remains to be proven (CALM - NC T01235689) (1).

Despite the emphasis on mucosal healing as a key therapeutic goal, patient reported outc omes, which a re validated surveys in clinic al tria Is that qua ntify patient reported qualitative data, are being inc reasingly recognized as important because IBD has an impact on the patient beyond the effects of disease activity alone (2). The World Health Organization has proposed that optimal management of chronic disea ses such as IBD should involve an "integrated" approach, encompassing comprehensive bio-psycho-social assessment and multid isciplinary management. Such an approach has been

This is the author manuscript accepted for publication and has undergone full peer review but has not been through the copyediting, typesetting, pagination and proofreading process, which may lead to differences between this version and the Version of Record. Please cite this article as doi: 10.1111/jgh.13368

This article is protected by copyright. All rights reserved. 
associated with an improvement in psychosocial functioning and reductions in opiate use, hospita lization and in-patient health-care utilization (3).

Although an "integrated" approach should represent the standard of care for IBD, a recent report by Price Waterhouse Coopers commissioned by Crohn's and Colitis Australia (CCA) has indic ated that there are currently several ba miers to a chieving quality of ca re for patients with IBD in Australia. $\mathrm{IBD}$ care has been inconsistent and often ina dequate. Optimal mana gement should be "preventive" but current models are predomina ntly "reactive". Treating fla res of the disea se will not change the outc ome of IBD, which are chronic in nature. Access to a ppropria te and cost-effective servic es rema ins inc onsistent. Although it is recognized that IBD nurses play a key role in coordinating complex multid isc iplinary care, fund ing of IBD nurse positions is limited and center specific. An integrated evidence-based approach to quality improvement is therefore necessary and the National Quality of Care Audit currently being undertaken by CCA will hopefully shed further light on these issues.

Variation in practice rema ins a further ba mier to the delivery of quality health care. Coordination of care in IBD is complex and prone to human errors of "omission". Based on the premise that most errors in medic ine are errors of "omission" rather tha n errors of "commission", sta nda rdizing practice via clinical pathways for decision support may be one way of ma inta ining quality of care in IBD. 
A further strategy to address the complexities of chronic disea se management in IBD has been via an emerging approach to health care delivery referred to as "partic ipatory" health care models. Pa rtic ipatory medic ine involves a collaboration between patient and their physician and refers to a movement in which networked patients move from being merely passengers to responsible drivers of their health, and in which providers encourage and value them asfull partners. Participatory medic ine promotes patient involvement in their care with the view to enabling patients to help themselves.

Electronic Health (eHealth) tec hnologies such as web-based solutions, sma rtphone apps and telemedic ine represent modalities that may be used to facilitate participatory medic ine because the underlying principle of eHealth solutions is that they incorporate an element of self-management. Such an approach via virtual clinics has been found to reduce outpatient attendance visits by up to $20 \%$ of an IBD cohort (4). Patients relay their informa tion to a program or health-care tea $m$ who give them feedback. Patientscan then adjust their therapy based on pre-determined algorithms or seek medical assessments. eHealth interventions to date in IBD have been found to improve adherence, knowledge about the disease, quality of life, access to and communic ation with IBD physicians, and have been found to empower patients in the self-management of their disease to potentially reduce healthca re costs in IBD (4). However, the evidence behind eHealth in IBD remains limited. Outc ome measures have been heterogeneous. Clinician and 
patient input has been lacking and there has been limited uptake of eHealth interventions perhaps due to the dic hotomy between the functions that patients and clinic ia ns prionitize; patients prioritize functions that enhance convenience whereasgastroenterologists prioritize evidence and functions that promote compliance and adherence. A balance needs to be struck between empowering patients with shared decision making and functions that help improve compliance (5).

In summary, new models of care should encompass treatment targets that a re individually based. Collaboration between patients and physicians is required to achieve optimal outc omes. The growing burden of disea se in IBD has the potential to nega tively impact on the delivery of quality care. Novel solutions a re required to a vert a crisis. "Partic ipatory Health care Models" via eHealth stra tegies may offer a solution partic ula rly if they a re combined with objective measures of disea se activity such as CRP and fecal Calprotectin. It is anticipated that such an approach will help ensure long-term success via tighter control, thereby enabling ea rlier predic tion of disea se fla res and prevention of disease progression. eHealth therefore has the potential to break down ba miers to the delivery of quality of care in IBD.

\section{Acknowledgements}

The Gutsy Group provided research support. Feming has provided an unrestric ted educational grant. AbbVie has provided research support. PDC is supported by a David Bicka rt Clinician Research award from the University of 
Melboume and Bushell Postdoctoral award from the Gastroenterological Society of Australia (GESA).

\section{Confilicts of Interest}

PDC has received educ ational support, consulted on advisory boards and been a speaker at educational symposia sponsored by Shire, Fering, J anssen, AbbVie, Takeda and Baxter.

\section{References}

1. Peyrin-Biroulet L, Sandbom W, SandsBE, Reinisch W, Bemelman W, Bryant RV, et al. Selecting Thera peutic Targets in Inflammatory Bowel Disea se (STRIDE): Detemining Therapeutic Goals for Treat-to-Target. Am J

Gastroenterol. 2015;110(9):1324-38.

2. Williet N, Sand bom WJ, Peyrin-Biroulet L. Pa tient-reported outc omes as primary end points in clinic al tria ls of infla mmatory bowel disease. Clin Gastroenterol Hepa tol. 2014;12(8):1246-56 e6.

3. Mikocka-Walus AA, Tumbull D, Holtmann G, Andrews J M. An integrated model of care for inflammatory bowel disea se sufferers in Australia: development and the effects of its implementation. Infla mm Bowel Dis. 2012;18(8):1573-81.

4. Jackson BD, Gray K, Knowles SR, De CruzP. EHealth Technologies in Inflammatory Bowel Disease: A Systematic Review . J oumal Of Crohn's \& Colitis. 2016; In Press. 
5. Con D, De CruzP. Mobile Phone Appsfor Inflammatory Bowel Disea se Self-Ma nagement: A Systematic Assessment of C ontent and Tools. J MIR mHealth and uHealth. 2016;4(1):e13.

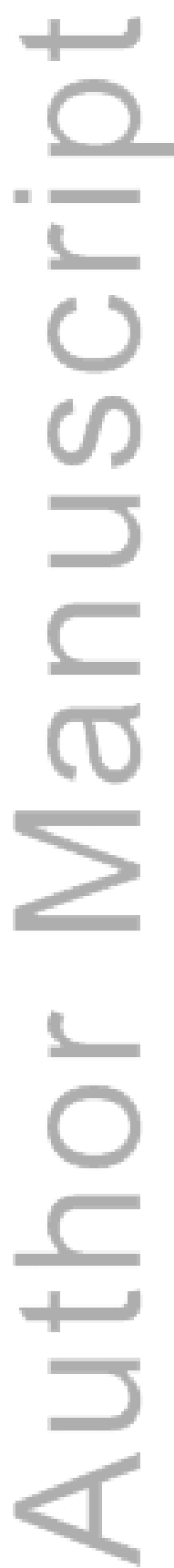

This article is protected by copyright. All rights reserved. 


\section{University Library}

\section{- M M I E E R VA A gateway to Melbourne's research publications}

Minerva Access is the Institutional Repository of The University of Melbourne

Author/s:

De Cruz, P

Title:

New models of care in IBD in changing times

Date:

2016-06-01

Citation:

De Cruz, P. (2016). New models of care in IBD in changing times. JOURNAL OF

GASTROENTEROLOGY AND HEPATOLOGY, 31, pp.40-41. https://doi.org/10.1111/ jgh. 13368.

Persistent Link:

http://hdl.handle.net/11343/291386 